\title{
Flavanones from Sorghum bicolor selectively inhibit COX-2: in-silico and in-vivo validation
}

\author{
O. Adeboye Akinloye ${ }^{1}$, D. Samuel Metibemu ${ }^{1,2^{*}}$, D. Ibukun Akinloye ${ }^{1}$, S. Bamidele Onigbinde ${ }^{1}$, \\ I. Abigail Olaosebikan ${ }^{1}$, Ogunnowo Florence ${ }^{1}$, Bashorun Damilola ${ }^{1}$ O. Adeola Bolarinwa ${ }^{1}$ and \\ Olaromilorun Olubunmi ${ }^{1}$
}

\begin{abstract}
Background: COX-2-specific inhibitors offer improved advantages over traditional NSAIDs. Plants are known to play critical roles in the discovery and developments of new pharmaceuticals. To the best of our knowledge, nothing has been reported so far on the selective inhibition of the cyclooxygenase by flavanones. The present study aims at evaluating the selective inhibition of COX-1 and/or COX-2 by flavanones from Sorghum bicolor.

Results: Flavanones demonstrate selective inhibition of COX-2 through the formation of hydrogen bonds. Eriodictyol forms two hydrogen bonds interactions (Tyr-371 and Ser-516) within the active site of COX-2, while it forms only one hydrogen bond (Met-521) with COX-1. Sorghum bicolor flavanone extract (SBFE) demonstrate hepatoprotective potentials by augmenting the antioxidant defense system of the liver and downregulate the expression of COX-2 while ineffective against COX-1. Histopathological analyses show that SBFE is effective in the prevention of $\mathrm{HCl} /$ ethanol-induced gastric injury in Wistar rats.
\end{abstract}

Conclusions: The side effects associated with current NSAIDs are as a result of selective inhibition of COX-1. Flavanones are potential selective inhibitors of COX-2. Sorghum bicolor flavanone extract (SBFE) demonstrates its anti-inflammatory potential through selective inhibition of COX-2. The virtual high throughput screening techniques adopted herein could help eradicate the corresponding rigors of identifying lead bioactive(s) components of plants.

Keywords: Molecular docking, Virtual high throughput screening (vHTS), Eriodictyol, Anti-inflammation, Cyclooxygenase-1 (COX-1), Cyclooxygenase-2 (COX-2)

\section{Background}

Inflammation is a biological reaction to disruption in the normal physiological processes [1]. It is a localized protective reaction of the tissues of the body to allergic or chemical irritation, injury, and/or infections. Inflammation is characterized by pain redness, swelling, and loss of functions [2].

Acute inflammation leads to the release of leukocytes, erythrocytes, and constituents of the plasma into the surrounding tissues affected by the inflammatory insults.

\footnotetext{
* Correspondence: damilohun.metibemu@aau.edu.ng

${ }^{1}$ Department of Biochemistry, Phytomedicine, Phyto-chemistry and

Bio-computing Research Laboratory, College of Biosciences, Federal

University of Agriculture, Abeokuta, Nigeria

${ }^{2}$ Department of Biochemistry, Faculty of Science, Adekunle Ajasin University, Akungba-Akoko, Ondo State, Nigeria
}

Chronic inflammation always results from acute inflammation, when the latter remains uncorrected. Chronic inflammation leads to the release of lymphocytes and macrophages into the affected tissue, and it is closely associated with allergies, atherosclerosis, cancer, arthritis, and Alzheimer's disease, as well as autoimmune diseases [3]. Non-steroidal anti-inflammatory drugs (NSAIDs) bring about their therapeutic effects through the inhibition of the cyclooxygenases (COX), the enzymes that produce the prostaglandins (PGs) [4]. Cyclooxygenase-1 (COX-1) is constitutive; its PGs protect the stomach and the kidney from damage, while cyclooxygenase-2 (COX2 ) is induced by inflammatory stimuli; its PGs contribute to the pain and swelling associated with inflammation. 
The anti-inflammatory effects of NSAIDs are due to the inhibition of COX-1 and COX-2. The unwanted side effects (irritation of the stomach lining and toxicity on the kidney) are as a result of the inhibition of COX-1 [4].

Chronic inflammation is often related to alcohol consumption [5]. Alcohol mediates activation of proinflammatory and anti-inflammatory genes in the liver [5]. Administration of hydrochloric acid $(\mathrm{HCl})$ and ethanol produces ulcerative lesions and increases lipid peroxidation in the gastric mucosa, which plays a significant part in the pathogenesis of the mucosal lesion [6].

Herbal and natural products are known for their biological and pharmacological activities [6]. Several drug candidates have been identified from plants, due to their reduced offensive factors, effectiveness in the treatment of certain ailments, better patient tolerance, and relatively affordable [7]. Medicinal plants have been reported to possess anti-inflammatory properties [8].

Virtual screening is an in-silico high throughput technique of screening compounds against biological target(s) and evaluation of the scoring. This technique gives a swift evaluation of vast libraries and prune down the number of compounds in order to pinpoint the hit compound(s) [9]. Molecular docking remains the most used virtual screening technique [10] and has turn out to be increasingly efficacious $[11,12]$.

In the present study, a total of 800 phytochemicals characterized from 17 medicinal plants [13-23]; Allium sativum, Aloe vera, Curcuma longa, Cymbopogon citratus, Dracaena arborea, Hibiscus sabdariffa, Moringa oleifera, Nicotiana tabacum, Ocimum gratissimum, Psidium guajava, Telfairia occidentalis, Vernonia amygdalina, Ziginber officinale, Amaranthus spinosus, Phoenix dactylefera, Plukenetia conophorum, and Sorghum bicolor were screened against the catalytic sites of COX-1 and COX-2. Sorghum bicolor is used in traditional medicine, for the primary care of anemia $[24,25]$ and in the treatment of various infectious diseases.

\section{Methods}

\section{Data collection and preparation}

A library of 800 characterized phytochemicals from 17 reported medicinal plants were created [13-23]. The phytochemicals were obtained from literature and downloaded in the Structure data format (Sdf format) from the PubChem database (https://pubchem.ncbi.nlm.nih.gov). Open babel was used to convert phytochemicals from their sdf formats to the protein data bank (pdb) formats. The ligprep command line was used to convert phytochemicals from the pdb formats to the protein data bank charged format (pdqt formats). The structure of COX-2 in complex with a benzopyran, (2R)-6,8-dichloro-7-(2-methylpropoxy)-2-(trifluoromethyl)-2H-chromene-3-carboxylic acid (3NTG with a crystallographic resolution of $2.19 \mathrm{~A}^{\circ}$ was adopted for virtual screening and docking because of its high resolution and a few numbers of co-crystallized compounds when compared with several other COX-2 protein in the PDB) [26] was downloaded from the protein data bank (http://www.rcsb.org). PyMOL plugin in Autodock/Vina was used to extract the receptor. The SWISSPdbViewer software was used to rebuild missing residues and atoms of the human COX-2 [27]. The experimental animals were randomized based on their body weight and allocated into six groups of five rats each.

\section{Structural modeling of human COX-1 and validation}

The human amino acids fasta sequences of COX-1 with accession number AAH29840.1 was obtained from the PubMed repository; this was used to carry out the homology model of COX-1 using the Swiss model server (swissmodel.expasy.org). The model was built on $2 \mathrm{OYE}$ [28] template with an identity of 92.8 and X-ray crystallography resolution of $2.8 \AA$ and grid coordinates set as obtained in the co-crystallized compound, $x=251.28, y$ $=108.48, z=-39.57$. The modeled protein structure was validated using the Procheck server (http://servicesn.mbi.ucla.edu/PROCHECK) [29]. The active site of the modeled protein was predicted with CASTP (sts.bioe.ulc.edu).

Molecular docking and virtual high throughput screening Virtual high throughput screening (vHTS), a computational technique used to screen a pool of compounds library against the target receptor, was used to screen phytochemicals against the binding pocket of COX-2 [23]. The grid coordinates were set exactly like those of the co-crystallized compound, $x=26.73, y=21.49, z=17.16$.

\section{Validation of docking results}

The co-crystallized ligand was re-docked into the catalytic site of COX-2 to validate the accuracy of the docking protocols [30, 31]. Root means square deviation (RMSD), a measure of the deviation of the co-crystallized from its initial geometry when re-docked, was used to access the deviation. When the value of the RMSD is less than $2.0 \AA$ for the re-docked pose and the co-crystallized pose, the docking protocol is accurate and fit to be used for the docking of other ligands to the receptor [32].

\section{Identification and preparation of plant materials}

The Sorghum bicolor grains were purchased from Osiele market, Abeokuta, Ogun State, Nigeria. The plant was taxonomically identified and authenticated at the Department of Botany, Federal University of Agriculture, Abeokuta, Ogun State, Nigeria. The Sorghum bicolor grains were air-dried in the dark and grounded into powder form prior to extraction and isolation. 


\section{Knowledge-based extraction of flavanones from Sorghum bicolor}

The vHTS technique employed revealed eriodictyol, a flavanone, as the lead. Hence, flavanones were extracted from the grains of sorghum bicolor using the method described by Bazzocchi et al. [33]. The finely grounded powdery Sorghum bicolor grains (900 g) were extracted with ethanol $(5 \mathrm{~L})$ in a soxhlet apparatus for a period of $24 \mathrm{~h}$ at around $80^{\circ} \mathrm{C}$. The solvent obtained from soxhlet extraction was evaporated under reduced pressure in a rotary evaporator at $\leq 50{ }^{\circ} \mathrm{C}$. The crude extract obtained was dissolved in $2.5 \mathrm{~L}$ of dichloromethane and allowed to stand for $48 \mathrm{~h}$. It was filtered; the filtrate was slowly poured into a separating funnel $(2 \mathrm{~L})$ placed onto a metallic stand. The filtrate was allowed to settle into immiscible phases, the organic phase (bottom layer), and the aqueous phase (top layer). The top layer was gently decanted off. The organic phase (bottom layer) was recovered and exposed in the dark for the volatile dichloromethane to escape, leaving the flavanone extract. The extract was weighed and recorded.

Calculations,

$$
\begin{aligned}
& \text { \% Yield }=\frac{\text { weight obtained }}{\text { Total weight }} \times 100 \% \\
& \begin{aligned}
\% \text { Yield } & =\frac{24.9 g}{900 g} \times 100 \% \\
& =2.77 \%
\end{aligned}
\end{aligned}
$$

\section{Experimental animal}

A sample size of 30 male Wistar rats was determined by using the G*Power 3 software for Mac OS [34], with the power set at 0.80 , alpha probability at 0.05 , and the effect size at 0.25 . The Wistar rats weighing between 150 and $250 \mathrm{~g}$ were purchased from the Institute for Advanced Medical Research and Training (IAMRAT), College of Medicine, University of Ibadan, Nigeria. They were acclimatized for 2 weeks before the onset of the experiment. The animals were housed in a wooden cage with good aeration. The animals were subjected to $12 \mathrm{~h}$ of light and $12 \mathrm{~h}$ of darkness. The animals were given standard diets and water ad libitum. The study was carried out in accordance with the Code of Ethics of the World Medical Association (Declaration of Helsinki) for experiments in animals. The experimental protocols were also reviewed and approved by the Institutional Animal Ethics Committee (IAEC).

\section{Experimental protocol}

The experimental animals were randomized based on their body weight and allocated into six groups of five rats each: i. Group A (basal control): animals received normal chow and water ad libitum.

ii. Group B (negative control): Animals received $1 \mathrm{ml}$ distilled water p.o for 8 days, followed by a single oral administration of $0.15 \mathrm{M} \mathrm{HCl} / 60 \%$ ethanol (ratio 1:1) [35] on the eight day and were sacrificed $5 \mathrm{~h}$ after.

iii. Group C (positive control): Animals received 50 $\mathrm{mg} / \mathrm{kg}$ body weight Diclofenac p.o for 8 days, followed by a single oral administration of $0.15 \mathrm{M}$ $\mathrm{HCl} / 60 \%$ ethanol (ratio 1:1) on the eight day and were sacrificed $5 \mathrm{~h}$ after.

iv. Group D (test group): animals received $50 \mathrm{mg} / \mathrm{kg}$ body weight Sorghum bicolor extract p.o for 8 days, a single oral administration of $0.15 \mathrm{M} \mathrm{HCl} / 60 \%$ ethanol (ratio 1:1) on the eight day, and were sacrificed $5 \mathrm{~h}$ after.

v. Group E (test group): received $100 \mathrm{mg} / \mathrm{kg}$ body weight Sorghum bicolor extract p.o for 8 days, a single oral administration of $0.15 \mathrm{M} \mathrm{HCl} / 60 \%$ ethanol (ratio 1:1) on the eight day, and were sacrificed $5 \mathrm{~h}$ after.

vi. Group F (test group): received $100 \mathrm{mg} / \mathrm{kg}$ body weight Sorghum bicolor extracts p.o for 8 days and were sacrificed $5 \mathrm{~h}$ after.

Note: animals' chow and water were withdrawn $24 \mathrm{~h}$ prior to sacrifice.

\section{Sacrifice, blood collection, and organs excision}

The experimental animals were sacrificed through cervical dislocation. The blood samples were collected via abdominal vein and centrifuged at $2500 \mathrm{rpm}$ for $10 \mathrm{~min}$. The supernatants were collected into clean Eppendorf tubes and stored for further biochemical assays. The Livers and the stomachs were also harvested, cleansed of superficial connective tissue in ice-cold normal saline, and later blotted with tissue paper and weighed. The tissues were homogenized for biochemical assays.

\section{Preparation of tissue homogenates}

The livers tissues were rinsed in cold sodium phosphate buffer $(1: 3, w / v)$, and subsequently homogenized with phosphate buffer, $\mathrm{pH}$ 7.4. The homogenate was centrifuged at $4000 \mathrm{rpm}$ for $10 \mathrm{~min}$, after which the clear supernatants were used for the various biochemical assays.

\section{Biochemical assays}

Determination of serum alanine aminotransferase activity The alanine aminotransferase (ALT) activity was determined according to the method described in Lab Kit, Canovelles, Barcelona. One tablet of the substrate was dissolved in $15 \mathrm{ml}$ of buffer, $30 \mu \mathrm{l}$ of the sample was added to 
$300 \mu \mathrm{l}$ of the working reagent, and the absorbance was taken every minute for $3 \mathrm{~min}$ at $340 \mathrm{~nm}$ [36].

Determination of serum aspartate aminotransferase activity Aspartate aminotransferase (AST) activity was determined according to the method described in Lab Kit, Canovelles, Barcelona. One tablet of the substrate was dissolved in $15 \mathrm{ml}$ of the buffer and $30 \mu \mathrm{l}$ of the sample was added to $300 \mu \mathrm{l}$ of the working reagent and the absorbance was taken every minute for $3 \mathrm{~min}$ at $340 \mathrm{~nm}$ [36].

Determination of liver superoxide dismutase activity Superoxide dismutase activity was determined by the method of Zou et al. [37]. The medium for the estimation was prepared as shown in the table below and the reaction was allowed to run for $60 \mathrm{~s}$ each time for $3 \mathrm{~min}$ before the absorbance was read against the reagent blank at $340 \mathrm{~nm}$.

\begin{tabular}{lll}
\hline & Test $(\mathrm{ml})$ & Blank $(\mathrm{ml})$ \\
Buffer & 0.10 & 0.15 \\
Distilled water & 0.83 & 0.83 \\
Sample & 0.05 & ------ \\
Incubate at $25^{\circ} \mathrm{C}$ for $10 \mathrm{~min}$. & & \\
Pyrogallol & 0.02 & 0.02 \\
\hline
\end{tabular}

Determination of lipid peroxidation Lipid peroxidation was determined by measuring the formation of thiobarbituric acid reactive substances (TBARS) according to the method of Buege and Aust [38].

This method is based on the reaction between 2thiobarbituric acid (TBA) and malondialdehyde.

Determination of liver reduced glutathione level The method of Beutler et al. [39] was followed in estimating the level of reduced glutathione (GSH). Then, $0.2 \mathrm{ml}$ of sample was added to $1.8 \mathrm{ml}$ of distilled water and $3 \mathrm{ml}$ of precipitating solution was mixed with sample. The mixture was allowed to stand for approximately $5 \mathrm{~min}$ and then filtered. At the end of the fifth minute, $1 \mathrm{ml}$ of filtrate was added to $4 \mathrm{ml}$ of $0.1 \mathrm{M}$ phosphate buffer. Finally, $0.5 \mathrm{ml}$ of Ellman's reagent was added and the optical density was measured at $412 \mathrm{~nm}$. A blank was prepared with $4 \mathrm{ml}$ of the $0.1 \mathrm{M}$ phosphate buffer, $1 \mathrm{ml}$ of diluted precipitating solution, and $0.5 \mathrm{ml}$ of the Ellman's reagent.

\section{Reverse transcription-polymerase chain reaction}

The total RNA of the liver tissues was isolated using TRIzol reagent (Gibco). The RNA was dissolved with the RNA-free DNase (Roche, Switzerland) for a period of 15 min at a temperature of $37{ }^{\circ} \mathrm{C}$. The RNeasy kit (Qiagen,
Germany) was used to purify the RNA. The cDNA was synthesized by incubating $40 \mu \mathrm{g}$ of the total RNA at $37^{\circ} \mathrm{C}$ for a period of $1 \mathrm{~h}$ with the reverse transcriptase (GE Healthcare, UK) and also with random hexanucleotides, following the manufacturer's instructions. The primers were designed using Snap gene software and ordered from Sigma-Aldrich, USA. The primers used to specifically amplify the genes of interest were,

\begin{tabular}{lll}
\hline $\begin{array}{l}\text { Target } \\
\text { gene } \\
\text { COX-2 }\end{array}$ & Forward 5'-3' & Reverse 5'-3' \\
COXAGCCATGCAGCAAATCC & GGGTGGGCTTCAGCAGTA \\
& AT \\
Cyclophilin & TGGAGAGTCACACAGCAAT & $\begin{array}{l}\text { CTGACAAGAAACAA } \\
\text { GAACAAG }\end{array}$ \\
& ACAGACA & TGCCGGAGTCGACAATGAT \\
\hline
\end{tabular}

Cyclophilin is the internal control gene. The genes were amplified for 50 cycles, $2 \mathrm{~h}$ and 20 min using the thermocycler. The amplified PCR products were run on $1.0 \%$ agarose gels and visualized with the aid of ethidium bromide (EtBr) staining [40].

\section{Histopathology studies}

The gastric mucosal tissues from the stomach of the experimental animals, groups A-F, were fixed in $10 \%$

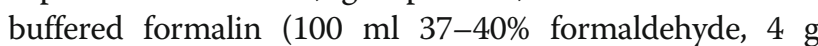
sodium phosphate monobasic, and $65 \mathrm{~g}$ of sodium phosphate dibasic in $900 \mathrm{ml}$ of distilled water, $\mathrm{pH}$ 7.0) for $24 \mathrm{~h}$ [41]. The fixative was removed by washing with running water overnight. After dehydration, the tissues were cleaned in methyl-benzoate and embedded in paraffin wax. The section was cut into 3-5 $\mu \mathrm{m}$ thickness and later stained with hematoxylin and eosin. The sections were mounted and observed under light microscope.

\section{Statistical analysis}

The results obtained were expressed as the means \pm standard error of mean (SEM). One-way analysis of variance (ANOVA) followed by Turkey's multiple range tests and one-tailed test statistics were used to analyze the results. Conformation to the assumptions of the ANOVA test was ascertained. $P<0.05$ were regarded as being significant, using the IBM-SPSS version 21.0 and GraphPad Prism version 7.0. The ImageJ software was used to quantify the bands from gene expression profiling (Fig. 1).

\section{Results}

Modeled protein validation

The modeled structure of COX-1 was validated using the Ramachadran plot (Fig. 2). From Fig. 2, there is a total of $99.6 \%$ of an allowed region and no disallowed region. 


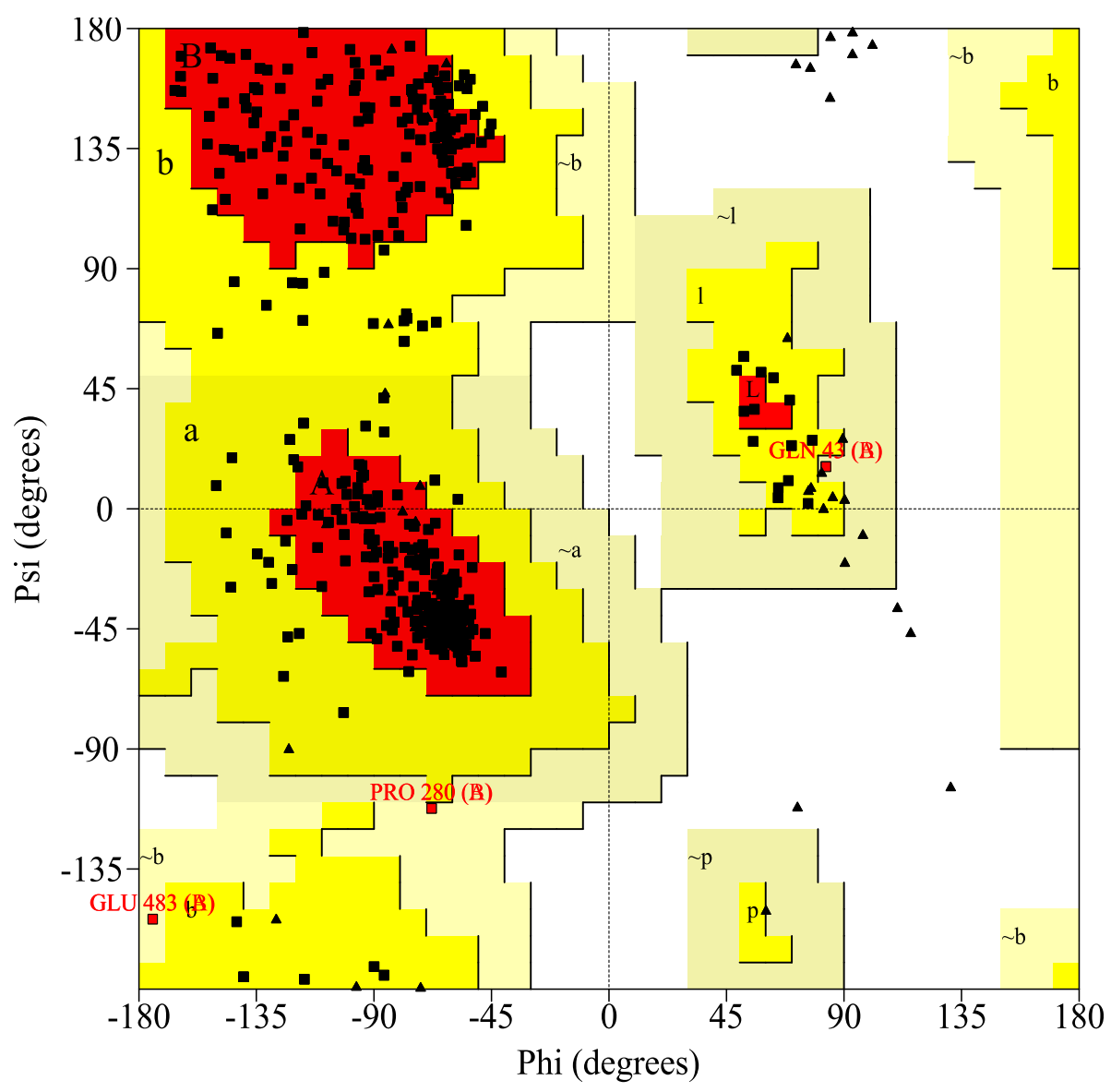

Plot statistics

Residues in most favoured regions [A,B,L]
Residues in additional allowed regions $[\mathrm{a}, \mathrm{b}, \mathrm{l}, \mathrm{p}]$
Residues in generously allowed regions $[\sim \mathrm{a}, \sim \mathrm{b}, \sim 1, \sim \mathrm{p}]$
Residues in disallowed regions
Number of non-glycine and non-proline residues
Number of end-residues (excl. Gly and Pro)
Number of glycine residues (shown as triangles)
Number of proline residues
Total number of residues

$\begin{array}{cc}826 & 87.9 \% \\ 110 & 11.7 \% \\ 4 & 0.4 \% \\ 0 & 0.0 \% \\ ---- & --- \\ 940 & 100.0 \% \\ 10 & \\ 86 & \\ 78 & \\ ---- & \\ 1114 & \end{array}$

Fig. 1 2D-structures of flavanones (eriodictyol, hesperetin, and naringenin) and NSAIDS

\section{Molecular docking and virtual high throughput screening} The virtual high throughput screening revealed eriodictyol (docking scores of $-8.4 \mathrm{kcal} / \mathrm{mol}$ with $\mathrm{COX}-2$ and -7.8 $\mathrm{kcal} / \mathrm{mol}$ with COX-1) (Fig. 1, Table 1), a flavanone as the lead compound (Table 1). In addition, the docking of other flavanones (Hesperetin and Naringenin) against COX-2 and COX-1 gave docking scores of $-8.5 \mathrm{kcal} /$ $\mathrm{mol}$ and $-7.3 \mathrm{kcal} / \mathrm{mol}$ respectively with Hesperetin and docking scores of $-7.8 \mathrm{kcal} / \mathrm{mol}$ and $-6.7 \mathrm{kcal} /$ mol respectively with Naringenin. Table 1 also shows the docking scores of standard selective inhibitors of both COX-2 and COX-1 (Fig. 3).

\section{Validation of docking results}

The co-crystallized, a benzopyran, (2R)-6,8-dichloro-7(2-methylpropoxy)-2-(trifluoromethyl)-2H-chromene-3carboxylic acid was re-docked back into the catalytic pocket of COX-2 (PDB ID: 3NTG). An RMSD value of $0.11 \AA$ was observed (Fig. 4).

\section{Biochemical assays}

Serum alanine aminotransferase

The level of alanine aminotransferase (ALT) was significantly increased in the group of animals given $\mathrm{HCl}$-ethanol only when compared with the basal control 


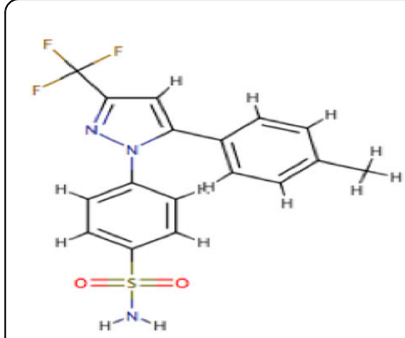

Celecoxib

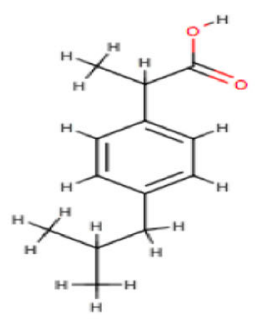

Ibuprofen

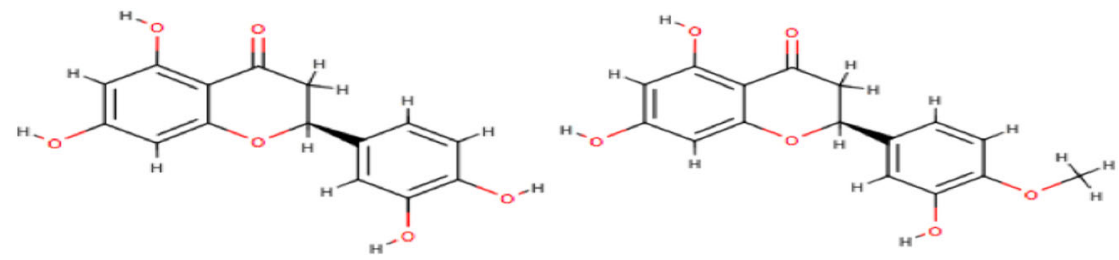

Eriodictyol

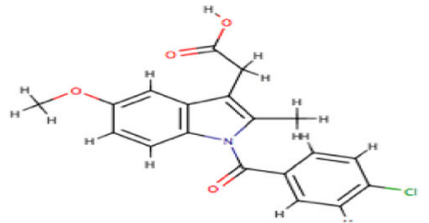

Indomethacin

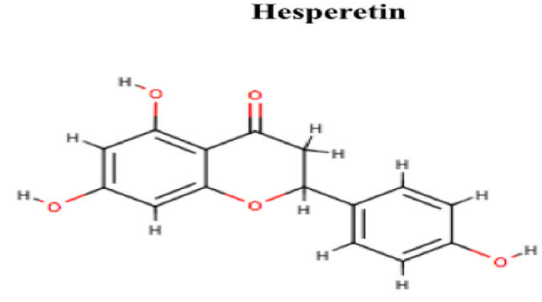

Naringenin

2D -Structures of Standard NSAIDs and Flavanones

Fig. 2 The Ramachandran plot of the model human COX-1

(Fig. 5a). The level of ALT was significantly attenuated in the groups that were pre-treated with Sorghum bicolor flavanone extract (SBFE) $(50 \mathrm{mg} / \mathrm{kg}$ and $100 \mathrm{mg} / \mathrm{kg})$. The level of ALT was also significantly reduced in the group given only SBFE $(100 \mathrm{mg} / \mathrm{kg})$ when compared with the basal control.

\section{Serum aspartate aminotransferase}

The level of aspartate aminotransferase (AST) was significantly increased in the group induced with $\mathrm{HCl} /$ ethanol only. There was no significant decrease in the level of serum AST in the group pre-treated with the diclofenac and later induced with $\mathrm{HCl} /$ ethanol when compared with the group induced with only $\mathrm{HCl} /$ ethanol (no pre-treatment) (Fig. 5b). However, there was a significant decrease in the level of serum AST in the groups pre-treated with $50 \mathrm{mg} / \mathrm{kg}$ and $100 \mathrm{mg} / \mathrm{kg}$ SBFE. In addition, there was a significant decrease in the level of serum AST in the group given only SBFE (Fig. 7) when compared with the group induced with $\mathrm{HCl} /$

Table 1 Docking scores of the lead, other flavanones (Hesperetin and Naringenin), and the standard drugs (Celecoxib, ibuprofen, Indomethacin)

\begin{tabular}{lll}
\hline Compounds & Docking scores COX-1 & Docking scores COX-2 \\
\hline Celecoxib & -10.3 & -11.2 \\
Eriodictyol & -7.8 & -8.4 \\
Hesperetin & -7.3 & -8.5 \\
Ibuprofen & -7.0 & -7.4 \\
Indomethacin & -8.9 & -7.2 \\
Naringenin & -6.7 & -7.8 \\
\hline
\end{tabular}

ethanol only. No significant differences were observed in the groups pre-treated with $50 \mathrm{mg} / \mathrm{kg}, 100 \mathrm{mg} / \mathrm{kg}$, and the group given only the SBFE when compared with the control.

\section{Liver glutathione}

The level of glutathione (GSH) was significantly reduced in the group administered with $\mathrm{HCl} /$ ethanol only, when compared with the basal control (Fig. 5c). The level of GSH was significantly reduced in the group pre-treated with $50 \mathrm{mg} / \mathrm{kg}$ diclofenac when compared with the basal control group and the group given only the $\mathrm{HCl} /$ ethanol. There was a significant increase in the level of GSH in the groups pre-treated with $50 \mathrm{mg} / \mathrm{kg}$ and $100 \mathrm{mg} / \mathrm{kg}$ SBFE when compared with the basal control (Fig. 5c).

\section{The superoxide dismutase}

As indicated in Fig. 5d, SBFE $(50 \mathrm{mg} / \mathrm{kg}, 100 \mathrm{mg} / \mathrm{kg}$, and $100 \mathrm{mg} / \mathrm{kg}$ of SBFE only) significantly elevated the level of SOD when compared with the basal control group and the groups administered $\mathrm{HCl} /$ ethanol only and diclofenac $+\mathrm{HCl} /$ ethanol. The SOD level was significantly decreased in the group administered $\mathrm{HCl} /$ ethanol only, and in the group pretreated with diclofenac (diclofenac $+\mathrm{HCl} /$ ethanol). In Fig. $5 \mathrm{~d}$, the SOD level of the group of animals given only $100 \mathrm{mg} / \mathrm{kg}$ of Sorghum bicolor flavanone extract (SBFE) was significantly increased when compared with the control.

\section{Lipid peroxidation}

The level of malondialdehyde (MDA) was significantly increased in the groups administered $\mathrm{HCl}$ /ethanol only 


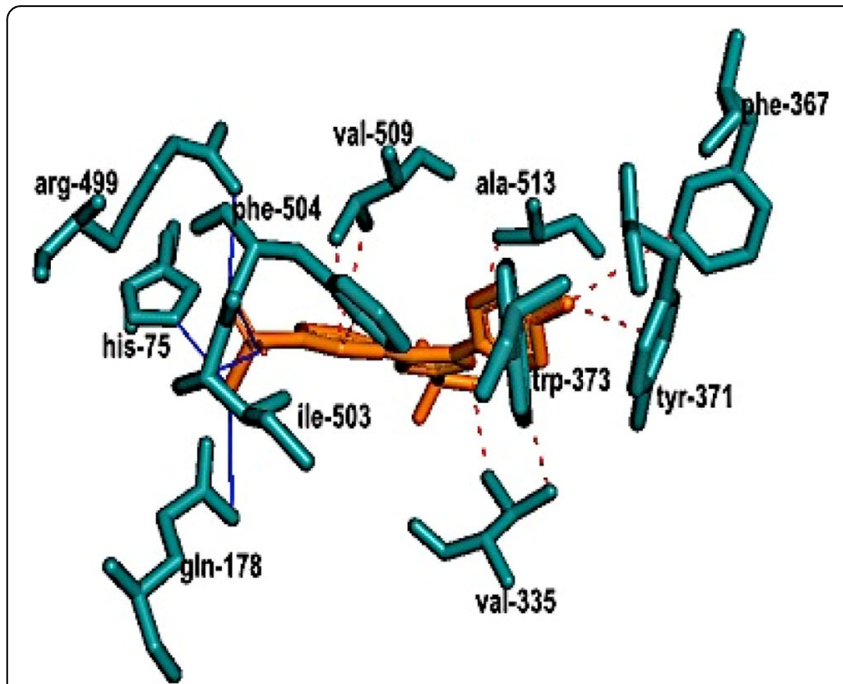

A

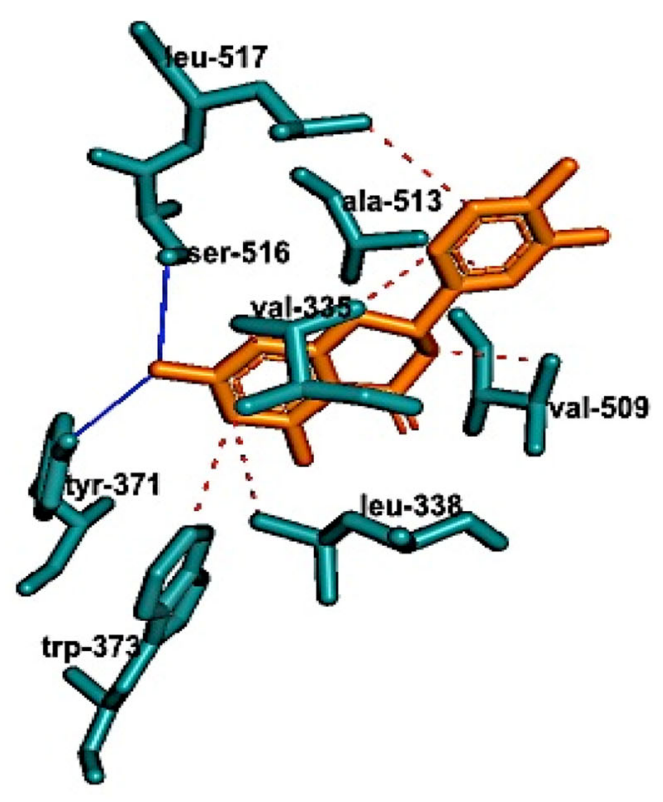

C

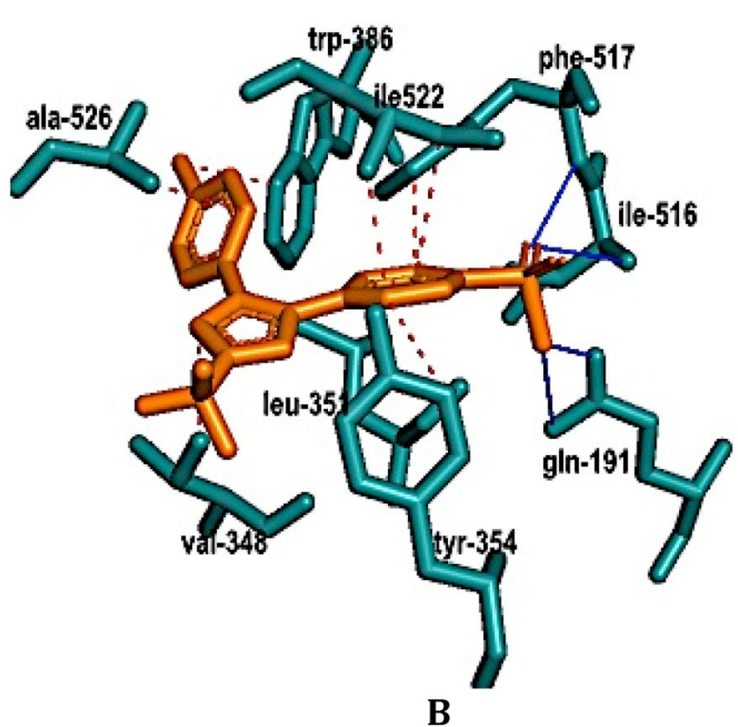

B

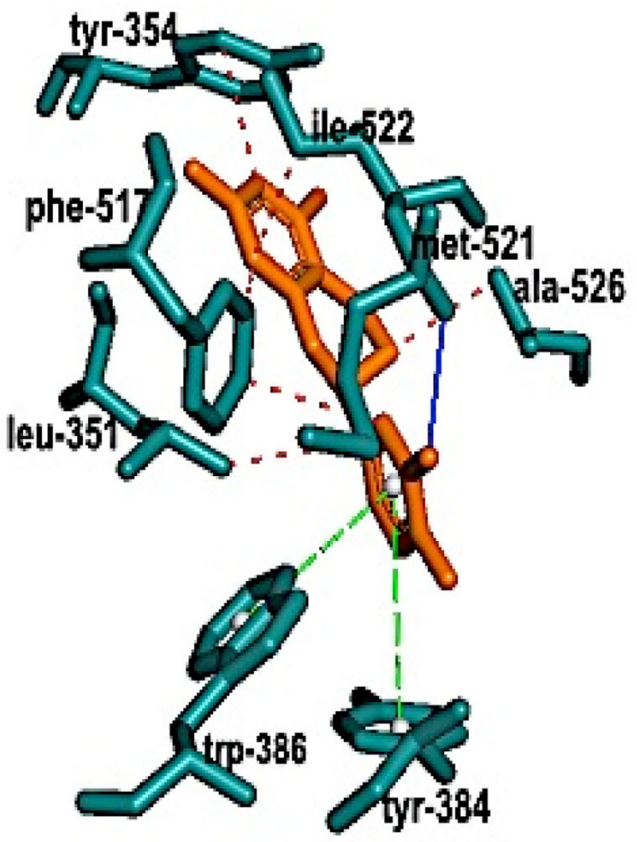

D

Fig. 3 a Interactions of celecoxib (orange) with key residues at the catalytic site of COX-2, the dotted red lines represent the hydrophobic interactions while the blue lines represent hydrogen bonds interactions. b Interactions of celecoxib (orange) with key residues at the catalytic site of COX-1; the dotted red lines represent hydrophobic interactions while the blue lines represent hydrogen bonds interactions. $\mathbf{c}$ Interactions of eriodicytol (orange) with key residues at the catalytic site of COX-2; the dotted red lines represent hydrophobic interactions while the blue lines represent hydrogen bonds interactions. $\mathbf{d}$ Interactions of eriodicytol (orange) with key residues at the catalytic site of COX-1; the dotted red lines represent hydrophobic interactions, the blue lines represent hydrogen bonds interactions and the dotted green lines represent Pi-stacking 


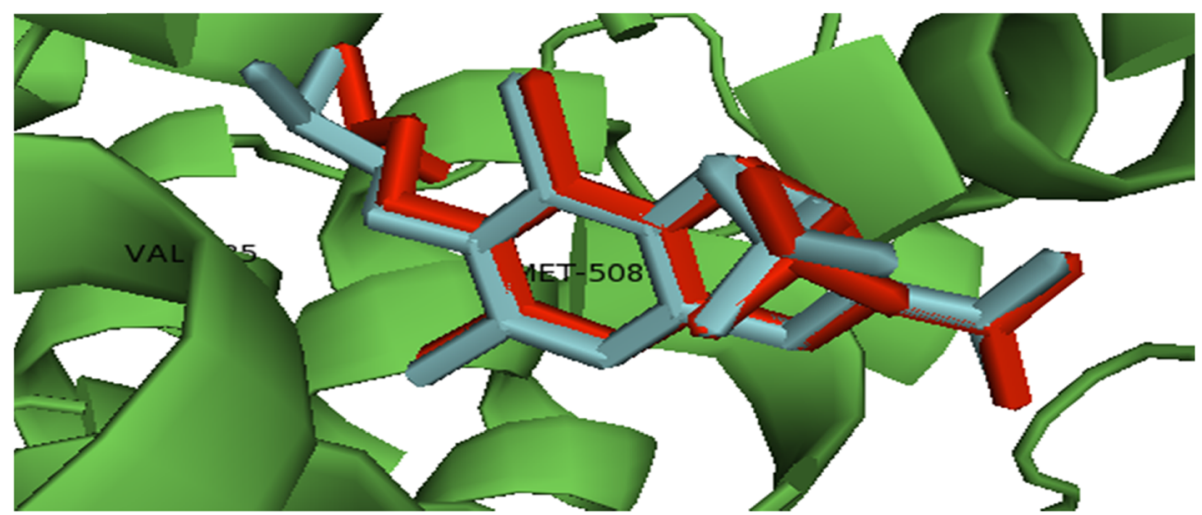

Fig. 4 The binding mode of the re-docked (cyan) and the co-crystallized, aspirin (red) within the active site of COX-2

and in the group pre-treated with diclofenac (Fig. 5e). However, there were no significant differences in the groups pre-treated with SBFE $(50 \mathrm{mg} / \mathrm{kg}$ and $100 \mathrm{mg} /$ $\mathrm{kg}$ ) and the groups treated with only $100 \mathrm{mg} / \mathrm{kg}$ SBFE when compared with the control.

\section{Gene expression profiling of the cyclooxygenases COX-2 gene}

In Fig. 6a, the administration of $\mathrm{HCl} /$ ethanol only (negative control) and diclofenac $+\mathrm{HCl} /$ ethanol (positive control) significantly upregulate the expression of COX-2 gene when compared with the basal control. However, in the groups pre-treated with $\mathrm{SBFE}(\mathrm{HCl}+\mathrm{ETOH}+50 \mathrm{mg} /$ $\mathrm{kg}$ and $\mathrm{HCl}+\mathrm{ETOH}+100 \mathrm{mg} / \mathrm{kg}$ ), there was significant downregulation of the expression of the COX-2 gene when compared to the basal control, negative control, and positive control (Fig. 6a).

\section{COX-1 gene}

In Fig. 6b, COX-1 expression was upregulated in the negative control ( $\mathrm{HCl} /$ ethanol only). There was no obvious downregulation in the expression of COX-1 in the positive control group and in the groups pre-treated with SBFE and later induced with $\mathrm{HCl} /$ ethanol $(50 \mathrm{mg} / \mathrm{kg}$ and $100 \mathrm{mg} / \mathrm{kg}$ of SBFE) when compared with the negative control.

\section{Histopathology analyses of the gastric mucosal tissues}

Figure $7 \mathrm{a}$ reveals the microscopic view of the gastric mucosa tissue of the basal control. Figure $7 \mathrm{~b}$ shows the microscopic view of the gastric mucosa tissue of the negative control $(\mathrm{HCl} /$ ethanol). Figure $7 \mathrm{c}$ shows the microscopic view of the gastric mucosa tissue of the positive control (diclofenac $+\mathrm{HCl} /$ ethanol). Figure $7 \mathrm{~d}$ shows the microscopic view of the gastric mucosa tissue of the group pre-treated with $50 \mathrm{mg} / \mathrm{kg}$ Sorghum bicolor flavanone (SBFE). Figure 7e reveals the microscopic view of the gastric mucosa tissue of the group pre-treated with $100 \mathrm{mg} / \mathrm{kg}$ Sorghum bicolor flavanone extract (SBFE) while Fig. $7 f$ reveals the microscopic view of the gastric mucosa tissue of the group treated with $100 \mathrm{mg} / \mathrm{kg}$ Sorghum bicolor flavanone extract (SBFE) only.

\section{Discussion}

\section{Modeled protein validation}

The modeled structure of COX-1 possess $99.6 \%$ allowed region and no disallowed region as validated with the Ramachadran plot (Fig. 2), which shows that our model is good and a true representation of human COX-1.

Molecular docking and virtual high throughput screening The virtual high throughput screening revealed eriodictyol (Fig. 1), a flavanone, as the lead compound (Table 1). In addition, molecular docking of other flavanones (hesperetin and naringenin) shows that they possess selective inhibitory potentials against COX-2 (Table 1).

This is in accordance with various reports that have hitherto implicated flavanones as anti-inflammatory compounds [42-44]. The selective potential of COX-2 inhibitors depends on the replacement of histidine 513 and isoleucine 523 of COX-1 with the smaller arginine and valine respectively. This replacement removes the restriction at the mouth of the secondary side channel and allows access for the bulkier selective COX-2 inhibitors [45]. It appears that the selectivity of inhibitors to COX-2 is due to hydrogen bonds interactions (Table 2) [46]. Eriodictyol forms two hydrogen bonds interactions (Tyr-371 and Ser-516) within the active site of COX-2, while it forms only one hydrogen bond (Met-521) with COX-1 (Fig. 3c, d).

\section{Validation of docking results}

The re-docked pose overlaps almost completely with the experimental orientation (Fig. 4). This gives credence to 


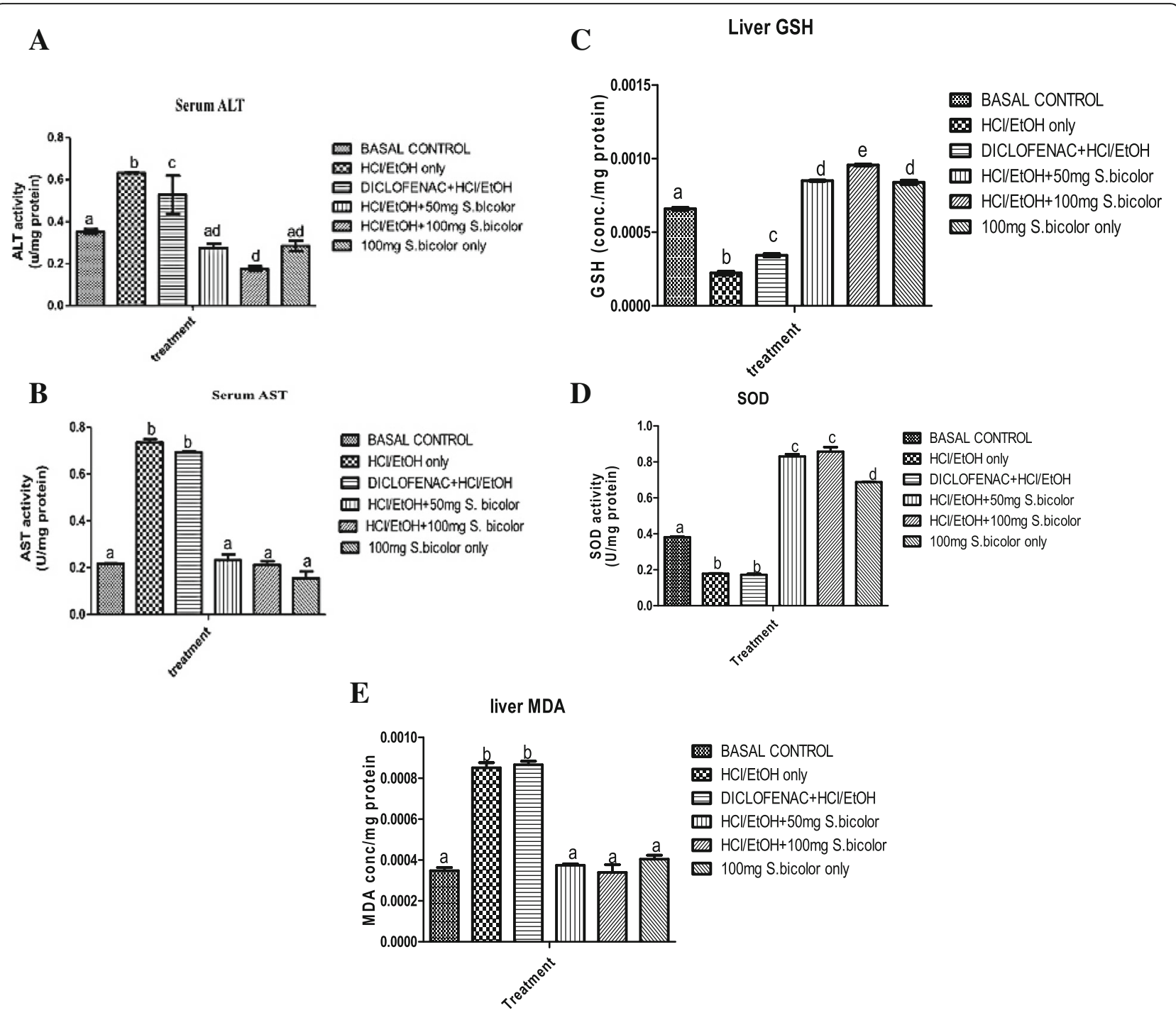

Fig. 5 a Effect of SBFE on $\mathrm{HCl} /$ ethanol-induced changes in serum alanine aminotransferase activity. Values are expressed as mean \pm Standard error of mean ( $n=6 /$ group). $P<0.05$ is considered to be statistically significant. Bars with different alphabets are statistically significant. $\mathbf{b}$ Effect of SBFE on $\mathrm{HCl} /$ ethanol-induced changes in serum aspartate transaminase activity. Values are expressed as mean \pm Standard error of mean ( $n=6$ /group). $P<0.05$ is considered to be statistically significant. Bars with different alphabets are statistically significant. c Effect of SBFE on HCl/ ethanol-induced changes in hepatic reduced glutathione levels. Values are expressed as mean \pm Standard error of mean $(n=6 /$ group). $P<0.05$ is considered to be statistically significant. Bars with different alphabets are statistically significant. $\mathbf{d}$ Effect of SBFE on $\mathrm{HCl} /$ ethanol-induced changes in hepatic superoxide dismutase activity. Values are expressed as mean \pm Standard error of mean ( $n=6 /$ group). $P<0.05$ is considered to be statistically significant. Bars with different alphabets are statistically significant. e Effect of SBFE on HCl/ethanol-induced changes in hepatic malondialdehyde (MDA). Values are expressed as mean \pm Standard error of mean ( $n=6 /$ group). $P<0.05$ is considered to be statistically significant. Bars with different alphabets are statistically significant

the accuracy of the auto-dock vina algorithm employed for molecular docking and virtual screening in the present study.

\section{Biochemical assays}

\section{Serum alanine aminotransferase}

An elevated serum alanine aminotransferase (ALT) and serum aspartate aminotransferase (AST) has been proposed as an indicator of alcohol-induced liver damage [47]. In the present study, the level of ALT was significantly increased in the group of animals given $\mathrm{HCl}$-ethanol only when compared with the basal control (Fig. 5a). This is an indication of liver damages [47]. The level of ALT was significantly attenuated in the groups that were pre-treated with Sorghum bicolor flavanone extract (SBFE) $(50 \mathrm{mg} / \mathrm{kg}$ and $100 \mathrm{mg} / \mathrm{kg})$. The level of ALT was also significantly reduced in the group given only SBFE $(100 \mathrm{mg} / \mathrm{kg})$ when compared with the basal 


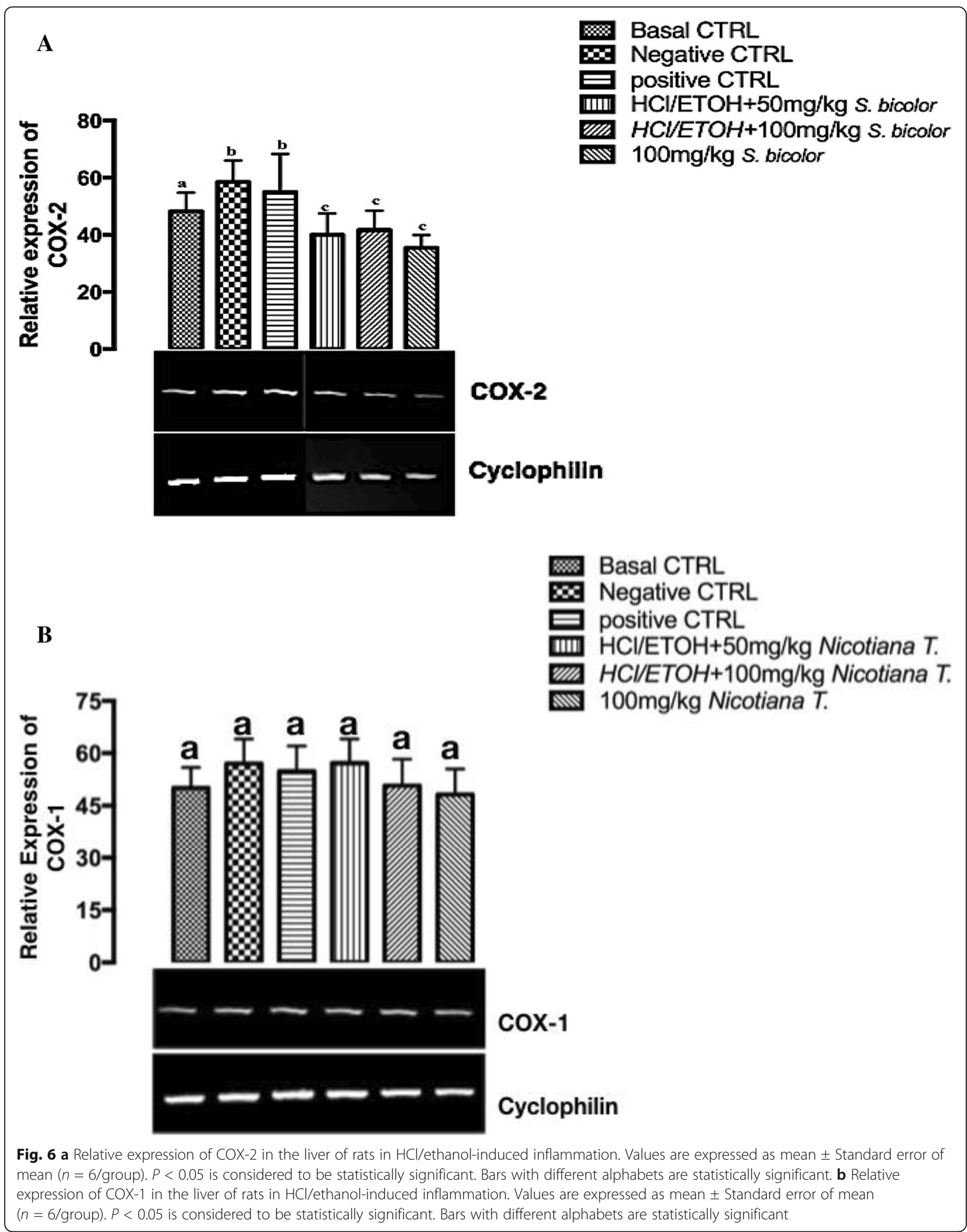




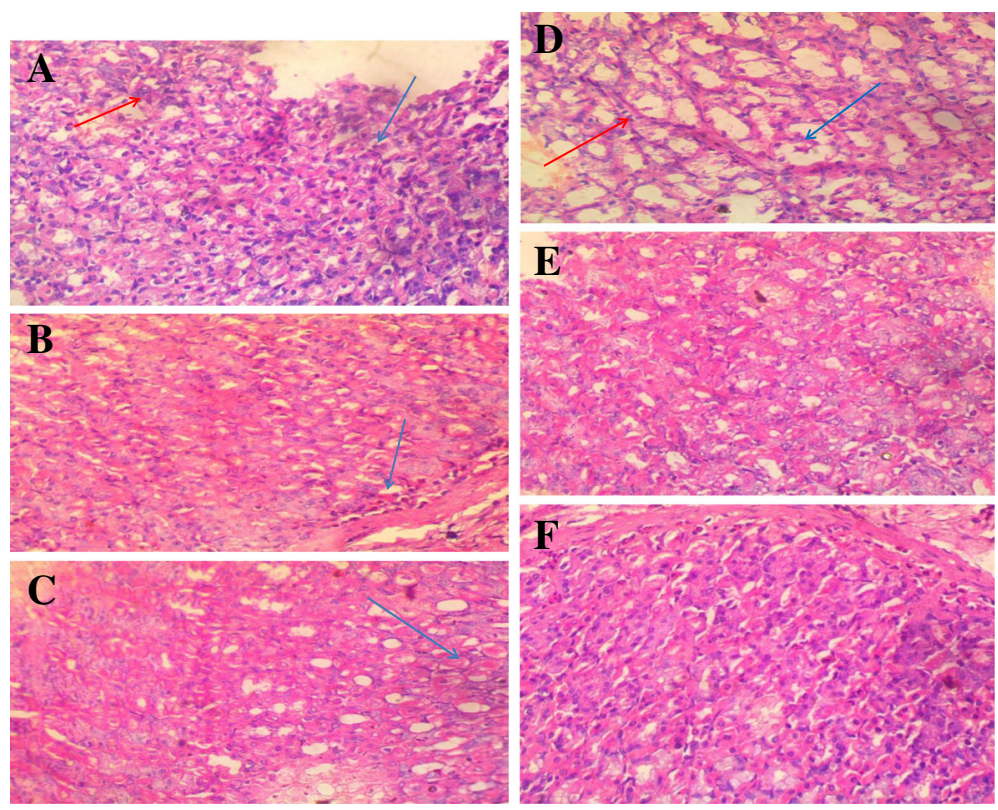

Fig. 7 a The basal control group, magnification of $\times 100$. b Negative control, magnification of $\times 400$. c The positive control, magnification of $\times$ 400. $\mathbf{d}$ Effects of the pre-treatment of $50 \mathrm{mg} / \mathrm{kg}$ Sorghum bicolor flavanone (SBFE) on the gastric tissue of $\mathrm{HCl} /$ ethanol-induced inflammation in rats, magnification $\times 400$. e Effects of the pre-treatment of $100 \mathrm{mg} / \mathrm{kg}$ Sorghum bicolor flavanone (SBFE) on the gastric tissue of $\mathrm{HCl} / \mathrm{ethanol-}$ induced inflammation in rats, magnification $\times 400$. $\mathbf{f}$ Effects of $100 \mathrm{mg} / \mathrm{kg}$ Sorghum bicolor flavanone extract (SBFE) only on the gastric tissue of the experimental animals, magnification $\times 100$

Table 2 Amino acids interactions of Celecoxib and the lead, Eriodictyol with COX-2 and COX-1

$\begin{array}{lc}\text { Hydrogen bond } & \text { Hydrophobic } \\ \text { Interactions } & \text { Interactions }\end{array}$

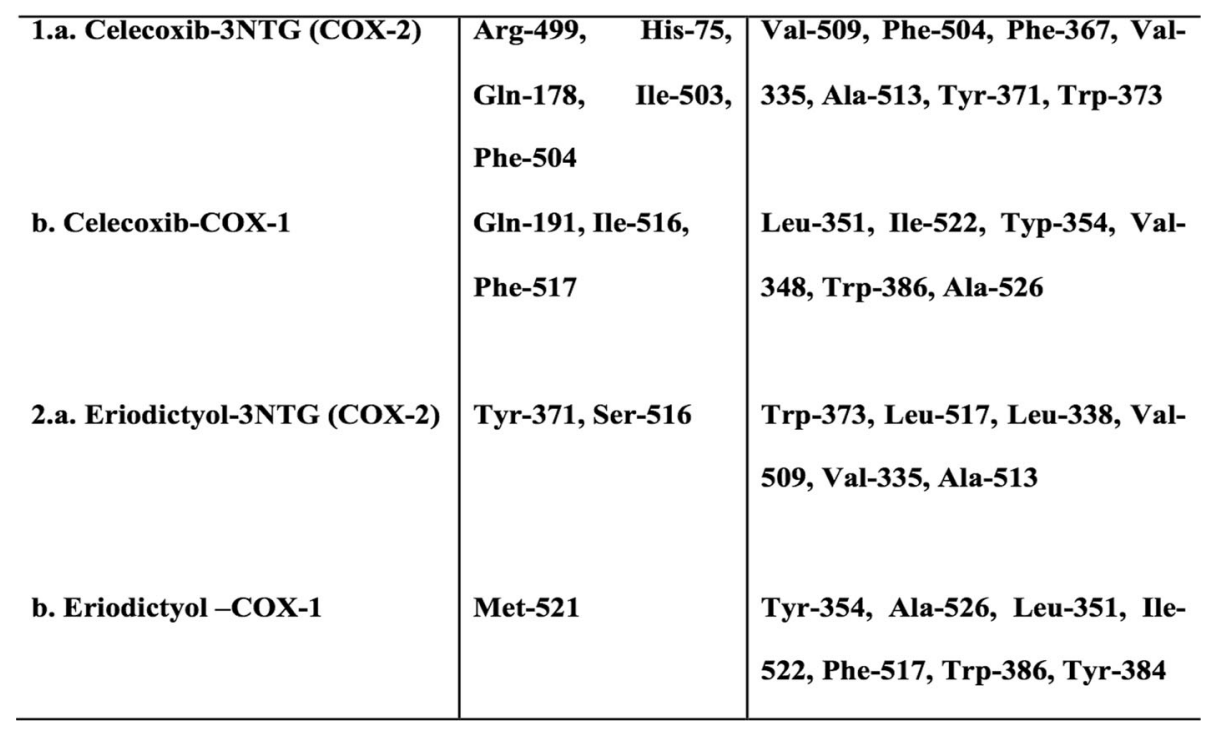


control. It is evident from the present study that SBFE possesses hepatoprotective effects; this is in agreement with the report of Agbaje et al. [48].

\section{Serum aspartate aminotransferase}

The level of AST was significantly increased in the group induced with $\mathrm{HCl} /$ ethanol only, indicating liver damage. There was no significant decrease in the level of serum AST in the group pre-treated with the diclofenac and later induced with $\mathrm{HCl} /$ ethanol when compared with the group induced with only $\mathrm{HCl} /$ ethanol (no pretreatment) (Fig. 5b). However, there was a significant decrease in the level of serum AST in the groups pretreated with $50 \mathrm{mg} / \mathrm{kg}$ and $100 \mathrm{mg} / \mathrm{kg}$ SBFE. In addition, there was a significant decrease in the level of serum AST in the group given only SBFE (Fig. 7) when compared with the group induced with $\mathrm{HCl} /$ ethanol only. No significant differences were observed in the groups pre-treated with $50 \mathrm{mg} / \mathrm{kg}, 100 \mathrm{mg} / \mathrm{kg}$, and the group given only the SBFE when compared with the control. This confirms the hepatoprotective properties of Sorghum bicolor [48].

\section{Liver glutathione}

Glutathione (GSH) is an important antioxidant and cellsignaling regulator. GSH protect the cells against oxidative injury by reducing $\mathrm{H}_{2} \mathrm{O}_{2}$ and scavenging reactive oxygen and nitrogen radicals. In the present study, the level of GSH was significantly reduced in the group administered with $\mathrm{HCl} /$ ethanol only, when compared with the basal control (Fig. 5c). The reduced level of GSH may be as a result of $\mathrm{HCl} /$ ethanol-induced liver injury [49]. The level of GSH was significantly reduced in the group pre-treated with $50 \mathrm{mg} / \mathrm{kg}$ diclofenac when compared with the basal control group and the group given only the $\mathrm{HCl} /$ ethanol. The reduced level of GSH in this group (diclofenac $+\mathrm{HCl} /$ ethanol) may be as a result of synergistic oxidative loads of diclofenac and $\mathrm{HCl} /$ ethanol on the liver. Diclofenac has been reported to be hepatotoxic [50]. However, there was a significant increase in the level of GSH in the groups pre-treated with $50 \mathrm{mg} /$ $\mathrm{kg}$ and $100 \mathrm{mg} / \mathrm{kg}$ SBFE when compared with the basal control (Fig. 5c). It is observed here that the Sorghum bicolor extract maintains the liver integrity by augmenting the antioxidant defense system of the liver.

\section{The superoxide dismutase}

Superoxide dismutase is a detoxifying enzyme; it is a component of the first line of the defense system against reactive oxygen species (ROS). Superoxide dismutase (SOD) is the first detoxification enzyme and most powerful antioxidant in the cell. It is an important endogenous antioxidant enzyme that acts as a component of first-line defense system against ROS [51]. It catalyzes the dismutation of two molecules of superoxide anion to hydrogen peroxide and molecular oxygen and in the process rendering the potentially harmful superoxide anion less hazardous. AS indicated in Fig. 5d, SBFE (50 $\mathrm{mg} / \mathrm{kg}, 100 \mathrm{mg} / \mathrm{kg}$, and $100 \mathrm{mg} / \mathrm{kg}$ of SBFE only) significantly elevated the level of SOD when compared with the basal control group and the groups administered $\mathrm{HCl} /$ ethanol only and diclofenac $+\mathrm{HCl} /$ ethanol. The SOD level was significantly decreased in the group administered $\mathrm{HCl} / \mathrm{ethanol}$ only, and in the group pretreated with diclofenac (diclofenac $+\mathrm{HCl} /$ ethanol), it appears that the toxic effects of ethanol and diclofenac disrupt the antioxidant defense system of the liver and it is probably through the generation of free radicals [52]. As revealed in Fig. 5d, the SOD level of the group of animals given only $100 \mathrm{mg} / \mathrm{kg}$ of sorghum bicolor flavanone extract (SBFE) was significantly increased when compared with the control. The SBFE, due to its reported antioxidant properties [53], may act by augmenting the antioxidant SOD defense system of the liver.

\section{Lipid peroxidation}

The development of chronic liver damage has been shown to be associated with the onset of lipid peroxidation [54]. Malondialdehyde (MDA) has been reported to be the foremost product to evaluate lipid peroxidation [55]. The level of MDA was significantly increased in the groups administered $\mathrm{HCl} /$ ethanol only and in the group pre-treated with diclofenac (Fig. 5e). There were no significant differences in the groups pretreated with SBFE $(50 \mathrm{mg} / \mathrm{kg}$ and $100 \mathrm{mg} / \mathrm{kg})$ and the groups treated with only $100 \mathrm{mg} / \mathrm{kg}$ SBFE when compared with the control. $\mathrm{HCl} /$ ethanol and diclofenacinduced lipid peroxidation; however, the SBFE protect the liver from lipid-peroxidation.

\section{Gene expression profiling of the cyclooxygenases COX-2 gene}

The COX-2 gene encodes the inducible isozyme, cyclooxygenase-2. It is induced by specific inflammatory stimuli, suggesting that it is responsible for the prostanoid biosynthesis involved in inflammation and mitogenesis. In Fig. 6a, the administration of $\mathrm{HCl} /$ ethanol only (negative control) and diclofenac $+\mathrm{HCl} /$ ethanol (positive control) significantly upregulate the expression of COX-2 gene when compared with the basal control. However, in the groups pre-treated with SBFE $(\mathrm{HCl}+$ $\mathrm{ETOH}+50 \mathrm{mg} / \mathrm{kg}$ and $\mathrm{HCl}+\mathrm{ETOH}+100 \mathrm{mg} / \mathrm{kg}$ ), there were significant downregulation of the expression of the COX-2 gene when compared to the basal control, negative control, and positive control (Fig. 6a). It is obvious from the result herein (Fig. 6a) that SBFE downregulates the expression of the pro-inflammatory COX-2 
gene. The anti-inflammatory potential demonstrated by SBFE (Fig. 6a) is likely due to its inhibition of COX-2.

\section{COX-1 gene}

This converts arachidonic acid to prostaglandin $\mathrm{H} 2$ (PGH2). It is involved in the constitutive production of prostanoids in particular in the stomach and platelets. It plays an important role in cytoprotection. It promotes platelet activation and aggregation, vasoconstriction, and proliferation of vascular smooth muscle cells through the generation of thromboxane A2 (TXA2). In Fig. 6b, COX-1 expression was upregulated in the negative control $(\mathrm{HCl} /$ ethanol only). However, there was no obvious downregulation in the expression of COX-1 in the positive control group and in the groups pre-treated with SBFE and later induced with $\mathrm{HCl} / \mathrm{ethanol}(50 \mathrm{mg} / \mathrm{kg}$ and $100 \mathrm{mg} / \mathrm{kg}$ of SBFE) when compared with the negative control. The downregulation of the expression of COX2 by SBFE (Fig. 6a) and the inability of the same SBFE to downregulate the expression of COX-1 (Fig. 6b) is likely due to the selective inhibition of COX-2 by SBFE.

\section{Histopathology analyses of the gastric mucosal tissues}

The gastric mucosal tissues from the stomach of the experimental animals from groups A-F were fixed in $10 \%$ buffered formalin and stained with hematoxylin and eosin. Figure $7 \mathrm{a}$ reveals the microscopic view of the gastric mucosa tissue of the basal control. In this group, there are locally extensive foci of mild erosion (blue arrow) of the surface covering epithelial cells of the gastric mucosa. There are a few foci of mild hyperplasia of mucus neck cells (red arrow). Other tunics show no visible lesion.

Figure $7 \mathrm{~b}$ shows the microscopic view of the gastric mucosa tissue of the negative control $(\mathrm{HCl} /$ ethanol). In this group, all tunics appear fairly normal. There are a few amounts of inflammatory cells at the base of the mucosa (blue arrow).

Figure 7c shows the microscopic view of the gastric mucosa tissue of the positive control (diclofenac $+\mathrm{HCl}$ / ethanol). In this group, all tunics appear fairly normal. However, there are a few foci of mild cloudy degeneration of a few parietal cells (arrow).

Figure $7 \mathrm{~d}$ shows the microscopic view of the gastric mucosa tissue of the group pre-treated with $50 \mathrm{mg} / \mathrm{kg}$ Sorghum bicolor flavanone (SBFE). There is a widespread loss (blue arrow) of mucous cells of the mucous glands of the tunica mucosa. Parietal cells (red arrow) show varying degrees of cloudy degeneration.

Figure $7 \mathrm{e}$ reveals the microscopic view of the gastric mucosa tissue of the group pre-treated with $100 \mathrm{mg} / \mathrm{kg}$ Sorghum bicolor flavanone extract (SBFE). All tunics appear normal. No visible lesion.
Figure $7 \mathrm{f}$ also reveals the microscopic view of the gastric mucosa tissue of the group treated with $100 \mathrm{mg} /$ kg Sorghum bicolor flavanone extract (SBFE) only. All the tunics appear normal and there was no visible lesion.

The histopathological analyses demonstrate that SBFE is effective in the prevention of $\mathrm{HCl}$ /ethanol-induced gastric injury in Wistar rats (Fig. 7a-f). COX-1 inhibitors are associated with a number of side effects including gastrointestinal erosions and renal and hepatic insufficiency; SBFE demonstrates its anti-inflammatory potential without any of such effects (Fig. 7a-f).

\section{Conclusion}

The side effects of current NSAIDs are as a result of selective inhibition of COX-1. To the best of our knowledge, nothing has been reported so far on the selective inhibition of COX-2 by flavanones. The present study established that flavanones are selective inhibitors of COX-2. This study shows that novel and potent hits could be generated via the virtual high throughput screening techniques applied herein.

\section{Abbreviations \\ COX-1: Cyclooxygenase-1; COX-2: Cyclooxygenase-2; ETOH: Ethanol; pdb: Protein data bank; pdqt formats: Protein data bank charged format; SBFE: Sorghum bicolor flavanone extract; Sdf format: Structure data format; VHTS: Virtual high throughput screening}

\section{Acknowledgements \\ We acknowledgement the Director of the Centre for Bio-computing and Drug Development, Adekunle Ajasin University Akungba-Akoko, Nigeria, Dr. I.O. Omotuyi for the use of the facilities at the Centre to carry some aspect of the research work.}

\section{Authors' contributions}

AOA proposed, design, and supervised the study, and he also edited the manuscript. MDS took part in all aspects of the study and wrote the manuscript. ADI wrote part of the manuscript, carried out biochemical assays, and analyzed the data. OSB carried out the in-silico screening, biochemical assays, and analyzed the data. OIA carried out the in-silico screening, the biochemical assays, and analyzed the data. OF carried out the insilico screening and the biochemical assays. BOA participated in the Molecular Gene Expression profiling while $\bigcirc \bigcirc$ participated in the histopathological analysis. All authors have read and approved the manuscript.

\section{Funding}

Not applicable.

\section{Availability of data and materials}

The data and materials for this study are available on request.

\section{Ethics approval and consent to participate}

The study was carried out in accordance with the Code of Ethics of the World Medical Association (Declaration of Helsinki) for experiments in animals. The experimental protocols were reviewed and approved by the Institutional Animal Ethics Committee (IAEC) with the acceptance number, FUNAAB/ IAEC /1712001.

Consent for publication

The consent for publication is obtained from all the authors.

Competing interests

The authors declare that they have no competing interests. 
Received: 25 June 2019 Accepted: 25 September 2019

Published online: 27 December 2019

\section{References}

1. Medzhitov R (2008) Origin and physiological roles of inflammation. Nature 445:153

2. Parham P (2000) The immune system, Chapter 1. Elements of the immune systems and their roles in defense. Garland Publishing, New York, pp 1-31

3. Maffetone, P. (2002). The ABCs of chronic inflammation. [Online]. Available http://content.bandzoogle.com/users/cippianhotmail/files/ABCs_of_ Inflammation_update_4-08(1).pdf.

4. Vane JR, Botting RM (1998) Anti-inflammatory drugs and their mechanism of action. Inflammation Research 47(Supplement 2):S78-S87

5. Wang HJ, Zakhari S, Jung MK (2010) Alcohol, inflammation, and gut-liverbrain interactions in tissue damage and disease development. World Journal of Gastroenterology 16(11):1304-1313 https://doi.org/10.3748/wjg. v16.i11.1304

6. Ito M, Shii D, Segami T, Kojima R, Suzuki T (1992) Preventive action of N-(3aminopropionyl)-L-hitidinato zinc (Z-103) through increases in the activities of oxygen derived free radicals scavenging enzymes in the gastric mucosa on ethanol induced gastric mucosal damage in rats. Japanese Journal of Pharmacology 59:267

7. Goel RK, Sairam K (2002) Antiulcer drugs from indigenous sources with emphasis on Musa sapientum, Tamrabhasna, Asparagus racemosus and Zingiber officinale. Indian Journal of Pharmacology 34:100-110

8. Amirghofran Z (2012) Herbal medicines for immunosuppression. Indian Journal of Pharmacology 11:111-119

9. Kontoyianni M (2017) Docking and virtual screening in drug discovery. Proteomics for Drug Discovery:255-266. https://doi.org/10.1007/978-14939-7201-2 18

10. Sethia, Joshi K, Sasikala K, Alvala M (2019) Molecular docking in modern drug discovery: principles and recent applications. IntechOpen. https://doi. org/10.5772/intechopen.85991

11. Kumar S, Sinha K, Sharma R, Purohit R, Padwad Y (2019) Phloretin and phloridzin improve insulin sensitivity and enhance glucose uptake by subverting PPARY/Cdk5 interaction in differentiated adipocytes. Experimental Cell Research. S0014-4827(19):30320-30329. https://doi.org/10. 1016/j.yexcr.2019.06.025

12. Tanwar G, Purohit R (2019) Gain of native conformation of Aurora A S155R mutant by small molecules. Journal of Cellular Biochemistry. https://doi.org/ 10.1002/jcb.28387

13. Shah BN, Seth AK, Maheshwari KM (2011) A review on medicinal plants as a source of anti-inflammatory agents. Research Journal of Medicinal Plants 5: 101-115

14. Bayan L, Koulivand PH, Gorji A (2014) Garlic: a review of potential therapeutic effects. Avicenna Journal of Phytomedicin 4(1):1-14

15. Sharma P, Amit C, Kharkwal AC, Kharkwal H, Abdin MZ, Varma A (2014) A review on pharmacological properties of Aloe vera. International Journal of Pharmaceutical Sciences Review and Research 29(2):31-37

16. Louay $L$ (2014) Medicinal and pharmacological properties of turmeric (Curcuma longa) A review. International Journal of Pharmacy and Biomedical Sciences 5(1):17-35

17. Shah G, Shri R, Panchal V, Sharma N, Singh B, Mann AS (2011) Scientific basis for the therapeutic use of Cymbopogon citratus, stapf (Lemon grass). Journal of Advanced Pharmaceutical Technology and Research 2(1):3-8 https://doi.org/10.4103/2231-4040.79796

18. Yakubu MT, Ajiboye TO, Akanji MA (2014) Toxicity and beneficial effects of some african plants on the reproductive system. Toxicological Survey of African Medicinal Plant:445-492

19. Minaiyan M, Asghari G, Taheri D, Saeidi M, Nasr-Esfahani S (2014) Antiinflammatory effect of Moringa oleifera Lam. seeds on acetic acid-induced acute colitis in rats. Avicenna Journal of Phytomedicine 4(2):127-136

20. Nacoulma AP, Compaore M, Lorenzi M, Kiendrebeogo M, Nacoulma OG (2012) In vitro antioxidant and anti-inflammatory activities of extracts from Nicotiana tabacum L. (Solanaceae) leafy galls induced by Rhodococcus fascians. Journal of Phytopathology. https://doi.org/10.1111/j.1439-0434. 2012.01953.x

21. Ajayi A, Tanayen J, Ezeonwumelu J, Dare S, Okwanachi A, Adzu B, Ademowo $O$ (2014) Anti-inflammatory, anti-nociceptive and total polyphenolic content of Hydroethanolic extract of Ocimum gratissimum
L. leaves. African Journal of Medicine and Medical Sciences 43(Suppl 1): 215-224

22. Jang M, Jeong S, Cho SK, Ahn KS, Lee JH, Yang DC, Kim J (2014) Antiinflammatory effects of an ethanolic extract of guava (Psidium guajava L.) leaves in vitro and in vivo. Journal of Medicinal Food 17(6):678-685. https:// doi.org/10.1089/jmf.2013.2936

23. Benson KF, Beaman JL, Ou B, Okubena A, Okubena O, Jensen GS (2013) West African Sorghum bicolor leaf sheaths have anti-inflammatory and immune-modulating properties in vitro. Journal of Medicinal Food 16(3): 230-238 https://doi.org/10.1089/jmf.2012.0214

24. Erah PO, Asonye CC, Okhamaf AO (2003) Response of Trypanosoma brucei brucei-induced anaemia to a commercial herbal preparation. African Journal of Biotechnology 2:307-311

25. Oladiji AT, Jacob TO, Yakubu MT (2007) Anti-anaemic potentials of aqueous extract of Sorghum bicolor (L.) Moench stem bark in rats. Journal of Ethnopharmacology 111:651-656

26. Wang JL, Limburg D, Graneto MJ, Springer J, Hamper JRB, Liao S, Pawlitz JL, Kurumbail RG, Maziasz T, Talley JT, Kiefer JR, Carter J (2010) The novel benzopyran class of selective cyclooxygenase-2 inhibitors. Part 2: The second clinical candidate having a shorter and favorable human half-life. Bioorganic and Medicinal Chemistry Letters. 20:7159-7163

27. Bordoli L, Kiefer F, Arnold K, Benkert P, Battery J, Schwede T (2009) Protein structure homology modelling using Swiss-MODEL workspace. Nature Protocols

28. Harman CA, Turman MV, Kozak KR, Marnett LJ, Smith WL, Garavito RM (2007) Structural basis of enantioselective inhibition of cyclooxygenase-1 by S-a-substituted indomethacin ethanolamides. The Journal of Biological Chemistry 282(38):28096-28105

29. Laskowski RA, Rullmannn JA, MacArthur MW, Kaptein R, Thornton JM (1996) AQUA and PROCHECK-NMR: programs for checking the quality of protein structures solved by NMR. Journal of Biomolecular NMR 8:477-486 [PubMed id: 9008363]

30. Shoichet BK (2004) Virtual screening of chemical libraries. Nature 432(7019): 862-865

31. Durrant JD, Amaro RE, McCammon JA (2009) AutoGrow: a novel algorithm for protein inhibitor design. Chemical Biology and Drug Design 73:168-178

32. Morris GM, Goodsell DS, Halliday RS, Huey R, Hart WE, Belew RK, Olson AJ (1998) Automated docking using a Lamarckian genetic algorithm and an empirical binding free energy function. Journal of Computational Chemistry 19:1639-1662

33. Bazzocchi IL, Ticona JC, Jiménez IA, Flores N (2016) Isolation of flavonoids from Piper delineatum leaves by chromatographic techniques. Bio protocols. 6(I):14 www.bio-protocol.org/e1867

34. Faul F, Erdfelder E, Buchner A, Lang AG (2009) Statistical power analyses using G*Power 3.1: Tests for correlation and regression analyses. Behavior Research Methods 41:1149-1160

35. Oian Y, Li G, Zhu K, Sun P, Feng X, Zhao X (2013) Effect of resistant starch on $\mathrm{HCl} /$ ethanol-induced gastric injury in rats. Journal of the Korean Society for Applied Biological Chemistry 56:613-619. https://doi.org/10.1007/s13765013-3143-4

36. Murray R (1984) Aspartate aminotransferase. In: Kaplan A et al (eds) Clin Chem The C.V. Mosby Co. Princeton, St Louis, pp 1112-1116

37. Zou GL, Gui XF, Zhong XL, Zhu YF (1986) Improvement in pyrogallol autoxidation method for the determination of SOD activity. Progress in Biochemistry and Biophysics 4:71-73

38. Buege JA, Aust SD (1978) Microsomal lipid peroxidation. Methods in Enzymology 52:302-310

39. Beutler E, Duron O, Kelly BM (1963) Improved method for the determination of blood glutathione. Journal of Laboratory and Clinical Medicine 61:882-888

40. Zhao X, Deng XX, Park KY, Qiu LH, Pang L (2013) Purple bamboo salt has anticancer activity in TCA8113 cells in vitro and preventive effects on buccal mucosa cancer in mice in vivo. Experimental and Therapeutic Medicine 5:549-554

41. Raghuramulu N, Madhavan KN, Kalyansundhram S (1983) A manual of laboratory techniques. NIN, ICMR, Silver Prints, Hyderabad, India

42. Yilma AN, Singh SR, Dennis VA (2013) Flavonoid naringenin: a potential immunomodulator for Chlamydia trachomatis inflammation. Mediators of Inflammation 102457. https://doi.org/10.1155/2013/102457

43. Yang HL, Chen SC, Kumar SKJ, Yu KN, Chao LPD, Tsai SY, Hou YC (2012) Antioxidant and anti-inflammatory potential of hesperetin metabolites 
obtained from hesperetin-administered rat serum: an ex vivo approach. Journal of Agricultural and Food Chemistry, 11 60(1):522-532. https://doi. org/10.1021/jf2040675

44. Bzeouich IM, Mutsapha N, Sassi A, S. (2016) Investigation of immunomodulatory and anti-inflammatory effects of eriodictyol through its cellular anti-oxidant activity. Cell Stress and Chaperones 21(5):773-78

45. Limongellia, V., Bonomia, M., Marinellib, L., Gervasioc, FL, Cavallid, A, Novellinob, E, and Parrinelloa, M. (2010). Molecular basis of cyclooxygenase enzymes (COXs) selective inhibition. www.pnas.org/cgi/doi/10.1073/pnas. 0913377107

46. Hermanson DJ, Gamble-George JC, Marnett L, Patel S (2014) Substrateselective COX-2 inhibition as a novel strategy for therapeutic endocannabinoid augmentation. Trends in Pharmacological Sciences 35(7): 358-367 https://doi.org/10.1016/j.tips.2014.04.006

47. Masano L, Mendez C, Hill D, Barve S, Macclain CJ (2003) Diagnosis and treatment of alcoholic liver diseases and its complications. Alcohol Research and Health 27(3):247-256

48. Agbaje MA, Nwoha PU, Adekomi DA, Olayode AA, Bamisi OD (2018) Tract of sorghum bicolor leaf sheath on paracetamol induced liver damage in rats. Journal of Medicine and Medical Sciences 9(1):009-014

49. Yuan L, Kaplowitz N (2009) Glutathione in liver diseases and hepatotoxicity. Molecular Aspects of Medicine:29-41

50. Boelsterl UA (2003) Diclofenac-induced liver injury: a paradigm of idiosyncratic drug toxicity. Toxicology and Applied Pharmacology 192(3):307-322

51. Ighodaro, OM and Akinloye, OA (2017). First line defence antioxidantssuperoxide dismutase (SOD), catalase (CAT) and glutathione peroxidase (GPX): Their fundamental role in the entire antioxidant defence grid. Alexandria Journal of Medicine. In press

52. Rasineni K, Casey CA (2012) Molecular mechanism of alcoholic fatty liver. Indian Journal of Pharmacology 44(3):299-303 https://doi.org/10.4103/02537613.96297

53. Dykes L, Rooney IW, Waniska RD, Rooney WI (2005) Phenolic compounds and antioxidant activity of sorghum grains of varying genotypes. Journal of Agricultural and Food Chemistry 53:6813-6818

54. Parola M, Leonarduzzi G, Robino G, Albano E, Poli G, Dianzani M (1996) On the role of lipid peroxidation in the pathogenesis of liver damage induced by long-standing cholestasis. Free Radical Biology and Medicine 20(3):351-359

55. Grotto D, Maria LS, Valentini J, Paniz C, Garcia GSS (2009) Importance of the lipid peroxidation biomarkers and methodological aspects for malondialdehyde quantification. Química Nova 32(1):169-174

\section{Publisher's Note}

Springer Nature remains neutral with regard to jurisdictional claims in published maps and institutional affiliations.

\section{Submit your manuscript to a SpringerOpen ${ }^{\circ}$ journal and benefit from:}

- Convenient online submission

- Rigorous peer review

- Open access: articles freely available online

- High visibility within the field

- Retaining the copyright to your article

Submit your next manuscript at $\boldsymbol{\nabla}$ springeropen.com 